\title{
Bioethanol production from Palmyrah (Borassus flabellifer) wastes using yeast
}

\author{
EJSBA Christy $^{1}$, S Mahilrajan ${ }^{2}$, G Chandrasena ${ }^{1}$ and R Kapilan ${ }^{3 *}$ \\ ${ }^{\prime}$ Uva Wellassa University, Passara Road, Badulla. \\ ${ }^{2}$ Palmyrah Research Institute, Kandy Road, Kaithady, Jaffna. \\ ${ }^{3}$ Department of Botany, Faculty of Science, University of Jaffna, Thirunelvely, Jaffna.
}

\begin{abstract}
This study describes bioethanol production from palmyrah (Borassus flabellifer L.) waste using yeast and optimization of fermentation conditions to increase the yield. When subjected to different pre-treatment conditions with various alkaline and acidic solutions, significantly higher reducing sugar contents were obtained from palmyrah coir dust with $\mathrm{H}_{2} \mathrm{SO}_{4}$ and $\mathrm{HNO}_{3}$ pre-treatments. $\mathrm{H}_{2} \mathrm{SO}_{4}$ pre-treatment at $3 \%, 5 \%$ and $7 \%$ concentrations for 15,30 , and 45 minutes respectively were given to the coir dust, and a significantly higher quantity of sugar was produced with $3 \% \mathrm{H}_{2} \mathrm{SO}_{4}$ after 45 minutes of reaction. Among the acids and bases used for the pre-treatment, $\mathrm{H}_{2} \mathrm{SO}_{4}$ is the best hydrolysing agent for coir dust. When fermentation was done with the coir dust hydrolysed solution under optimized conditions $\left[30{ }^{\circ} \mathrm{C}\right.$ and $\mathrm{pH} 5.0$ with baker's yeast $\left(6 \times 10^{6}\right.$ cells $\left.\mathrm{mL}^{-1}\right)$ and incubated in peptone, yeast extract and nutrient (PYN) medium at $30^{\circ} \mathrm{C}$ for 7 days] , a significantly higher amount of alcohol was produced on the $4^{\text {th }}$ day than the respective non-optimized conditions. Similarly, molasses and fruit pulp of palmyrah also produced significantly higher quantities of ethanol individually under similar optimized conditions used for coir dust on the $6^{\text {th }}$ and $4^{\text {th }}$ day of fermentation respectively, than the respective non-optimized conditions. The efficiency of alcohol fermentation by yeast with palmyrah coir dust acid hydrolysate was $19 \%$. Therefore, coir dust could also be used as a long-term substrate for bioethanol production, considering the excess availability of this underutilized waste material.
\end{abstract}

Keywords: Bioethanol, coir dust, fermentation, molasses, palmyrah, pre-treatment.

\section{INTRODUCTION}

Population growth and increased industrial activities have resulted in a rising concentration of greenhouse gases in the atmosphere causing the greenhouse effect. Bioethanol produced from biomass sources are one of the best alternatives for petroleum-based fuels and recently, they have been commonly used for transportation in many countries (Hill et al., 2006). Bioethanol is basically produced from first- or second-generation feedstocks. First generation bioethanol is produced from some cereals and legumes such as corn, sugar beet, wheat, and barley, which are used also as food sources. Sugars which are obtained from the first-generation feedstocks such as sugarcane, molasses, sugar beet, and fruits can be fermented via yeast directly. The advantages of these raw materials are, high sugar yields and low conversion cost. The disadvantage is limited availability of the raw materials during certain period of the year. While 25 gallons of ethanol is produced from an average of 1 ton sugar beet, 20 gallons of ethanol is produced from 1 ton of sweet sorghum stalk (Sarkar et al., 2012). Usage of this first-generation feedstock for bioethanol production has raised concerns about increasing food prices and occupation of agricultural land. These problems are solved partially by using second-generation feedstock lignocellulosic materials

\footnotetext{
*Corresponding author (ranganat@ualberta.ca; (D https://orcid.org/0000-0002-7608-1615)
} 
such as waste or forest residues (Nigam \& Singh, 2011). Second-generation feedstocks have some advantages over the first-generation feedstocks due to not being used as food sources and less land requirement. However, their harvesting, purification and various pre-treatment needs have made their production quite challenging and not economical (Daroch et al., 2013). During the past ten to fifteen years, biofuel has drawn attention as a potential environmentally friendly fuel because of diminishing petroleum reserves in the world, and the deleterious environmental effects of exhaust gases from petroleum (Vasudevan, 2008). Time has come to explore diverse natural plant and agricultural substrates that could produce biofuels efficiently (Kapilan, 2015). During the past five decades there has been a significant increase in studies on biofuel production by fermentation using diverse plant-based substrates including rice, corn, whey, molasses, sea weeds and cellulosic biomass (Qureshi \& Blaschek, 2005).

Palmyrah (Borassus flabellifer L.) is a tropical palm, belonging to the family Arecaceae and all its parts are of potential economic value (Mohanadas, 2002). Palmyrah palms are economically useful and widely cultivated, especially in Southeast Asia. Of the estimated 11 million palmyrah palms in Sri Lanka, 90\% are found in the three Districts of Jaffna, Mannar and Kilinochchi. Palmyrah palm has multiple uses: timber for construction, leaves for fencing, roofing and woven handicrafts, fibre for rope and sap for drinking. If the sap is left to ferment for a few hours, it becomes a mildly alcoholic, fragrant toddy. The young palmyrah roots are high in calcium and consumed as a snack, and is also ground to make flour for porridge called khool. Jaggery, a delicious golden-coloured unrefined palm sugar is made from unfermented palmyrah toddy. The germinated seeds of palmyrah palm form fleshy sprouts below the surface that can be boiled and eaten as a fibrous, nutritious food. The crunchy watery kernel is also edible and sweeter. The kernel inside the hard shell is an edible jelly that is rich in minerals. From the fleshy crown of the tree, cakes can be made. Products obtained from palmyrah are classified into edible and non-edible products (Asiri Nisansala et al., 2021). Among the palmyrah products are, expired bottled palmyrah fruit pulp (PFP), and molasses, which is the mother liquor left after the crystallization of juice. This dark coloured viscous liquid contains about $60 \%$ fermentable sugar that could be used for ethanol production. PFP is extracted from the ripe fruit and molasses is obtained from the sugar candy producing centres. Fibre is one of the non-edible products obtained from basal sheath of the palmyrah leaf. Fibres are mainly vascular bundles or groups of sclerenchymatous fibre cells. In Sri Lanka, until 1991, fibre was extracted manually from young (5-10 years old) palm trees. During the extraction of Coir fibre, dust is generated as the main waste (Theivendirarajah, 2008). Palmyrah coir dust is a spongy material which could be used for the production of bioethanol (Theivendirarajah, 2008). Lignocellulosic waste materials obtained from forestry and agricultural industries are generally not used as raw materials for the production of second-generation bioethanol. Even though coir dust is the principal and excessive waste material generated during the extraction of fibre from palmyrah palm, its utilization is very limited in the palmyrah palm growing regions (Theivendirarajah, 2008). The objective of this study was to produce bioethanol from palmyrah wastes; expired palmyrah fruit pulp, molasses and coir dust, using baker's yeast and to optimize the pre-treatment conditions to increase the yield

\section{METHODOLOGY}

\section{Collection of raw materials}

Palmyrah coir dust was collected from Sarasalai fibre industry, Jaffna District, Sri Lanka and molasses and expired PFP 3 months after expiry date (PEP shelf life is 12 months), were obtained from the Palmyrah Development Board, Jaffna, Sri Lanka.

\section{Chemical analysis}

\section{Determination of reducing sugar}

The reducing sugar content was determined by using 3, 5-Dinitrosalicylic acid (DNS) method. A series of standard glucose solutions were prepared by diluting different volumes ranging from $0.2-1.0 \mathrm{~mL}$ of a stock glucose solution $\left(1.0 \mathrm{gL}^{-1}\right)$ in a series of labelled test tubes. The total volume was made up to $1.0 \mathrm{~mL}$ with distilled water. DNS reagent $(1.0 \mathrm{~mL})$ was added, and the tubes were heated in a boiling water bath for $5 \mathrm{~min}$. The tubes were cooled, distilled water $(10.0 \mathrm{~mL})$ was added, and the absorbance was measured spectrometrically (Spectronic 21D) against a reagent blank at $550 \mathrm{~nm}$. The reagent blank was prepared by taking $1.0 \mathrm{~mL}$ of distilled water instead of standard glucose solution. Solutions of unknown concentrations (samples) were treated similarly, and their glucose concentrations were determined using the standard curve for glucose (Miller, 1959).

\section{Determination of acidity}

Acidity of the sample was measured by titrating with 0.1 $\mathrm{M} \mathrm{NaOH}$ solution using phenolphthalein as the indicator. Percentage acidity is expressed as millimoles of $\mathrm{NaOH}$ used per $100 \mathrm{~mL}$ of sap solution. 
Percentage acidity $=\frac{\text { Volume of } \mathrm{NaOH}(\mathrm{mL}) \times 0.1}{\text { Volume of sap solution }(\mathrm{mL})} \times 100$ $p H$

A sample was taken in a clean beaker $(25 \mathrm{~mL})$ and its $\mathrm{pH}$ was measured by using a digital $\mathrm{pH}$ meter (Sension $\mathrm{PH} 31$-Spain) at room temperature $\left(28 \pm 2{ }^{\circ} \mathrm{C}\right)$. The sample was returned to the fermentation vessel after measurement.

\section{Determination of alcohol}

Alcohol content of the fermented sample was determined directly for each sample by using Dujardin-Salleron ebulliometer and expressed in terms of percentage $(\mathrm{v} / \mathrm{v})$.

\section{Determination of brix}

The total soluble sugar content of the molasses and bottled PFP was analysed using a refractometer (Atago, Germany).

\section{Ethanol production from coir dust}

\section{Size Reduction}

Small sized particles of coir dust were chosen by filtering the coir dust using a sieve plate ( $40 \mathrm{~mm}$ diameter) for an efficient pre-treatment and hydrolysis.

\section{Pre-treatment of coir dust}

\section{Alkaline hydrolysis}

Alkaline hydrolysis of the coir dust was carried out by using $\mathrm{NaOH}$ and $\mathrm{Ca}(\mathrm{OH})_{2}$. Coir dust $(10 \mathrm{~g})$ was placed in a $250 \mathrm{~mL}$ Erlenmeyer flask and $100 \mathrm{~mL}$ of $5 \%(\mathrm{w} / \mathrm{v})$ alkaline solution was added separately. Then the flasks were plugged with cotton and autoclaved at $121{ }^{\circ} \mathrm{C}$ for 15 min. The substance obtained after treatment was dark in colour which was then filtered through muslin cloth and washed under running distilled water until no colour was observed in the wash water and made up to $100 \mathrm{~mL}$. Reducing sugar was determined by using the DNS method.

\section{Acid hydrolysis}

The same procedure used for alkaline hydrolysis was followed with three acid solutions; sulfuric acid, nitric acid and hydrochloric acid for acid hydrolysis of the coir dust, and the acids that produced high reducing sugar content were selected for further studies.

\section{Optimization of acid hydrolysis condition}

Coir dust (10g) was inoculated with different concentration of sulphuric acid (3,5 and 7\%) and hydrolysed at different time intervals $(15,30$ and $45 \mathrm{~min})$. Then the hydrolysate was filtered through a muslin cloth and washed under running distilled water until no colour was observed in the wash water and made up to $100 \mathrm{~mL}$. DNS method was used to determine the reducing sugar content. This experiment was repeated with nitric acid. Acid that resulted the highest reducing sugar content was selected as the best treatment for further studies.

\section{Preparation of yeast inoculum}

Peptone, yeast extract, and nutrient (PYN) medium (Balakumar \& Arasaratnam, 2009) was prepared and sterilized at $121^{\circ} \mathrm{C}$ for $15 \mathrm{~min}$. It was then inoculated with one loop of baker's yeast (Saccharomyces cerevisiae), incubated at $30^{\circ} \mathrm{C}$ for $18 \mathrm{~h}$ and used as the inoculum. The inoculum contained a cell density of $6 \times 10^{6}$ cells $\mathrm{mL}^{-1}$.

Table 1: Composition of peptone, yeast extract and nutrient (PYN) medium $(\mathrm{pH}=5.0)$

\begin{tabular}{lc}
\hline Medium & $\mathrm{g} / \mathrm{L}$ \\
\hline Peptone & 3.5 \\
Yeast extract & 3 \\
$\mathrm{MgSO}_{4}$ & 1 \\
$\mathrm{KH}_{2} \mathrm{PO}_{4}$ & 2 \\
$\left(\mathrm{NH}_{4} \mathrm{SO}_{4}\right)$ & 1 \\
Glucose & 50 \\
\hline
\end{tabular}

\section{Ethanol production from molasses and expired PFP}

Initial total soluble solid (TSS) content of molasses and PFP was adjusted to ${ }^{\circ} 15$ brix with sterile water and used for the fermentation studies.

\section{Fermentation}

Acid hydrolysate $(100 \mathrm{~mL})$ obtained from selected treatments of coir dust (with sulphuric acid and nitric acid), $100 \mathrm{~mL}$ of molasses and PFP were taken into separate conical flasks and adjusted to $\mathrm{pH} 5.0$ using $0.4 \mathrm{M} \mathrm{NaOH}$. Fermentation medium was added in the ratio of $10 \mathrm{~mL}$ of yeast inoculum to $100 \mathrm{~mL}$ of pretreated sample (1:10). Samples were taken at intervals of 24 hours for determination of alcohol, acidity, $\mathrm{pH}$ and reducing sugar. 


\section{Efficacy of fermentation}

Efficiency of alcohol fermentation was determined as follows.

Efficiency of fermentation $=\frac{\text { Actual ethanol content }}{\text { Theoretical value }} \times 100$

Theoretical ethanol content $=$ Total fermentable sugar $\times 0.64$

\section{Statistical analysis}

Each experiment was performed in triplicate and standard deviation for each experimental result was calculated using Microsoft Excel for graphical representation. Acid pre-treatments of coir dust were optimized using general full factorial design. Altogether nine treatments were carried out for one acid. Results obtained from the entire treatment was analysed using one way ANOVA and least significance difference (LSD) was tested using Turkeys comparison at 5\% confidence level using Minitab 17 software.

\section{RESULTS AND DISCUSSION}

\section{Results}

Based on the amount of reducing sugar production during hydrolysis at $121{ }^{\circ} \mathrm{C}$ for $15 \mathrm{~min}, \mathrm{H}_{2} \mathrm{SO}_{4}$ and $\mathrm{HNO}_{3}$ were selected as best hydrolysing agents since the production of reducing sugar was significantly higher with $\mathrm{H}_{2} \mathrm{SO}_{4}$ and $\mathrm{HNO}_{3}$ (more than $30 \mathrm{mg} / \mathrm{mL}$ reducing sugar) than the other agents (Table 2).
Table 2: Production of reducing sugars from palmyrah coir dust by different pre-treatment agents

\begin{tabular}{lcc}
\hline Pre-treatment & Agent & $\begin{array}{c}\text { Reducing sugar } \\
(\mathrm{mg} / \mathrm{mL})\end{array}$ \\
\hline Alkaline hydrolysis & $\mathrm{Ca}(\mathrm{OH})_{2}$ & $4.15( \pm 0.05)$ \\
& $\mathrm{NaOH}$ & $0.54( \pm 0.06)$ \\
Acid hydrolysis & $\mathrm{HCL}$ & $13.39( \pm 0.05)$ \\
& $\mathrm{HNO}_{3}$ & $36.19( \pm 0.12)$ \\
& $\mathrm{H}_{2} \mathrm{SO}_{4}$ & $34.92( \pm 0.11)$ \\
\hline
\end{tabular}

\section{Optimization of sulphuric acid $\left(\mathrm{H}_{2} \mathrm{SO}_{4}\right)$ pre-treatment}

Optimization of acid hydrolysis with $\mathrm{H}_{2} \mathrm{SO}_{4}$ was carried out with different concentrations of acid (3, 5 and 7\%) and different hydrolysis times (15, 30 and $45 \mathrm{~min})$. Altogether there were nine treatments as listed in Table 3. Main effects plot (Figure 1a) of response means for reducing sugar of each factor indicate that different levels of each factor affect the reducing sugar content.

According to the interaction plot (Figure 1b), it could be confirmed that there is an interaction between concentrations of acid and times of hydrolysis for the production of reducing sugar from coir dust. Treatment 7 (3\% and $45 \mathrm{~min})$ that produced significantly higher amount of reducing sugar was selected for further fermentation studies.

Table 3: Design for sulphuric acid pre-treatments with different concentrations of acid and different hydrolysed time for the production of reducing sugar from coir dust

\begin{tabular}{cccccc}
\hline $\begin{array}{c}\text { Std } \\
\text { order }\end{array}$ & $\begin{array}{c}\text { Run } \\
\text { Order }\end{array}$ & Blocks & $\begin{array}{c}\text { Hydrolysed } \\
\text { time }\end{array}$ & Concentration & $\begin{array}{c}\text { Reducing } \\
\text { sugar }(\mathrm{mg} / \mathrm{mL})\end{array}$ \\
\hline 1 & 1 & 1 & 1 & 1 & 34.628 \\
2 & 2 & 1 & 1 & 2 & 0.991 \\
3 & 3 & 1 & 1 & 3 & 0.34 \\
4 & 4 & 1 & 2 & 1 & 41.953 \\
5 & 5 & 1 & 2 & 2 & 0.545 \\
6 & 6 & 1 & 2 & 3 & 0.199 \\
7 & 7 & 1 & 3 & 1 & 40.154 \\
8 & 8 & 1 & 3 & 2 & 2.531 \\
9 & 9 & 1 & 3 & 3 & 2.021 \\
\hline
\end{tabular}




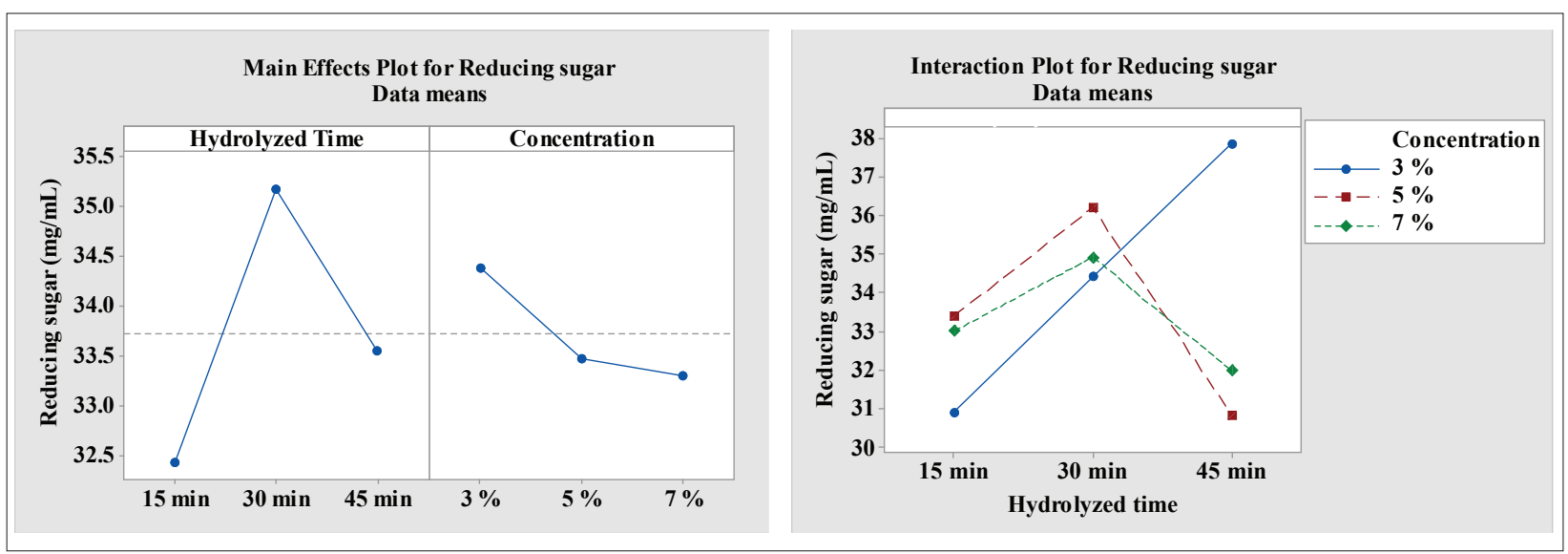

Figure 1: Effect of different concentrations and time on formation of reducing sugar with $\mathrm{H}_{2} \mathrm{SO}_{4}$ pre-treatment from coir dust

Table 4: Design for nitric acid pre-treatments with different concentrations of acid percentage and different hydrolysed time for the production of reducing sugar from coir dust

\begin{tabular}{cccccc}
\hline $\begin{array}{c}\text { Std } \\
\text { order }\end{array}$ & $\begin{array}{c}\text { Run } \\
\text { order }\end{array}$ & Blocks & $\begin{array}{c}\text { Hydrolysed } \\
\text { Time }\end{array}$ & Concentration & $\begin{array}{c}\text { Reducing sugar } \\
(\mathrm{mg} / \mathrm{mL})\end{array}$ \\
\hline 1 & 1 & 1 & 1 & 1 & 30.892 \\
2 & 2 & 1 & 1 & 2 & 33.385 \\
3 & 3 & 1 & 1 & 3 & 33.002 \\
4 & 4 & 1 & 2 & 1 & 34.408 \\
5 & 5 & 1 & 2 & 2 & 36.199 \\
6 & 6 & 1 & 2 & 3 & 34.920 \\
7 & 7 & 1 & 3 & 1 & 37.861 \\
8 & 8 & 1 & 3 & 2 & 30.828 \\
9 & 9 & 1 & 3 & 3 & 31.979 \\
\hline
\end{tabular}

Factor 1: Hydrolysed time (Level 1: $15 \mathrm{~min}$, Level 2: $30 \mathrm{~min}$, Level 3: $45 \mathrm{~min}$ )

Factor 2: Concentration (Level 1: 3\%, Level 2: 5\%, Level 3: 7\%)

\section{Optimization of nitric acid $\left(\mathrm{HNO}_{3}\right)$ pre-treatment}

Optimization of acid hydrolysis with $\mathrm{HNO}_{3}$ was carried out with different concentrations of acid (3,5 and 7\%) and different hydrolysed times (15, 30 and $45 \mathrm{~min})$. Altogether there were nine treatments (Table 4).

According to the interaction plot and main plot (Figure 2) of $\mathrm{HNO}_{3}$ pre-treatment, treatment 4 (3\% at 30 $\mathrm{min}$ ) that produced significantly higher amount of sugar was selected for further fermentation studies.

\section{Production of alcohol from coir dust acid hydrolysed solution}

Alcohol was not produced from $\mathrm{HNO}_{3}$ acid hydrolysed solution while $0.4 \%$ of alcohol was obtained at the $4^{\text {th }}$ day of fermentation from $\mathrm{H}_{2} \mathrm{SO}_{4}$ hydrolysed solution (Table 5). Although the concentration of reducing sugar was similar for $\mathrm{HNO}_{3}$ hydrolysed solution and $\mathrm{H}_{2} \mathrm{SO}_{4}$ hydrolysed solution, there was no alcohol production in $\mathrm{HNO}_{3}$ hydrolysed solution, probably due to the formation of toxic by-products during hydrolysis (Taherzadeh \& Karimi, 2007). 


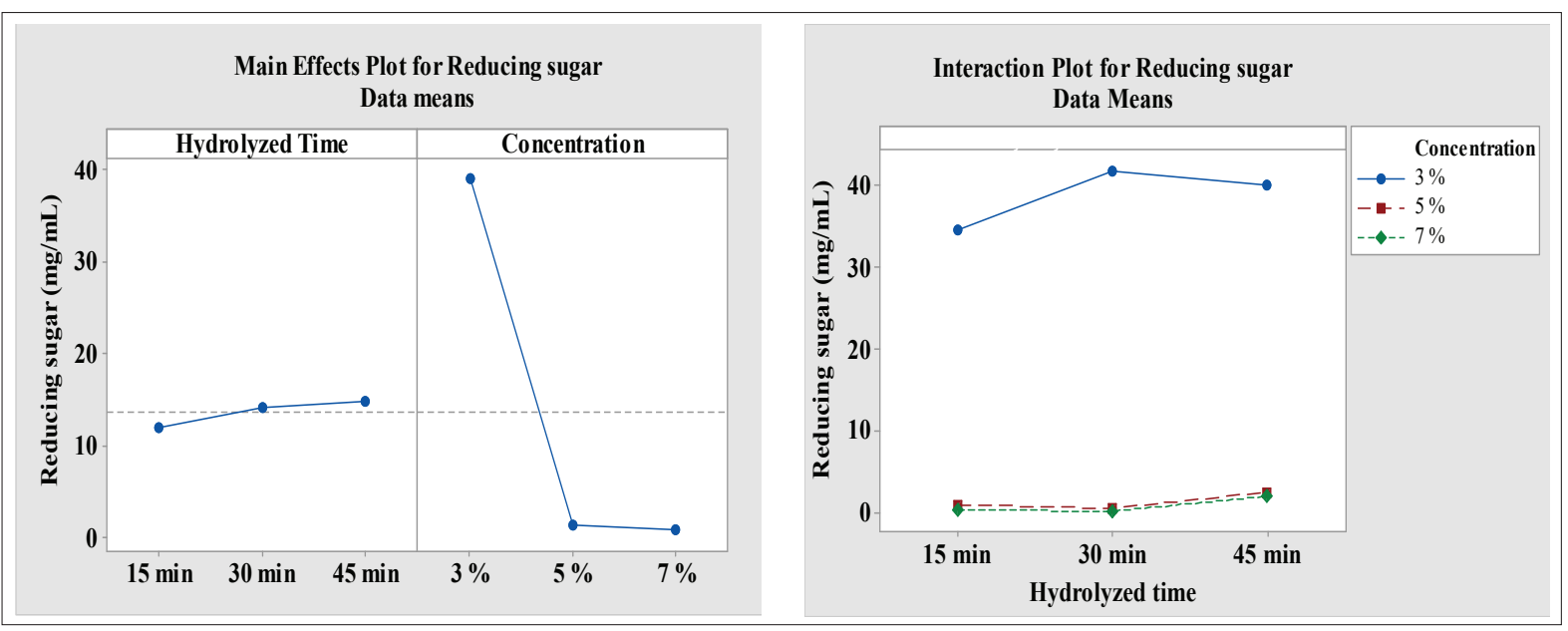

Figure 2: Effect of different concentrations and time on formation of reducing sugar with $\mathrm{HNO}_{3}$ pre-treatment from coir dust

Table 5: Changes in chemical characteristics of $\mathrm{H}_{2} \mathrm{SO}_{4}$ hydrolysed medium during fermentation

\begin{tabular}{cllll}
\hline $\begin{array}{c}\text { Fermentation } \\
\text { period (days) }\end{array}$ & Alcohol $(\%)$ & Acidity $(\%)$ & $\begin{array}{l}\text { Reducing sugar } \\
(\mathrm{mg} / \mathrm{mL})\end{array}$ & $\mathrm{pH}$ \\
\hline 2 & $0.1( \pm 0.008) \mathrm{d}$ & $3.17( \pm 0.03) \mathrm{b}$ & $33.3298( \pm 91.38) \mathrm{a}$ & $5.05( \pm 0.02) \mathrm{c}$ \\
3 & $0.2( \pm 0.009) \mathrm{c}$ & $2.87( \pm 0.08) \mathrm{c}$ & $22.2287( \pm 171.25) \mathrm{b}$ & $5.14( \pm 0.01) \mathrm{b}$ \\
4 & $0.4( \pm 0.01) \mathrm{a}$ & $2.64( \pm 0.07) \mathrm{d}$ & $14.9823( \pm 9.19) \mathrm{c}$ & $5.19( \pm 0.02) \mathrm{a}$ \\
5 & $0.4( \pm 0.01) \mathrm{a}$ & $3.16( \pm 0.08) \mathrm{b}$ & $0.9889( \pm 29.53) \mathrm{d}$ & $5.10( \pm 0.01) \mathrm{b}$ \\
6 & $0.3( \pm 0.009) \mathrm{b}$ & $4.85( \pm 0.05) \mathrm{a}$ & $0.9886( \pm 29.50) \mathrm{d}$ & $4.94( \pm 0.03) \mathrm{d}$ \\
\hline
\end{tabular}

Each value in the table is represented as mean $\pm \mathrm{SD}(\mathrm{n}=3)$. Values in the same column followed by a different letter (a-d) are significantly different $(\mathrm{p}<0.05)$.

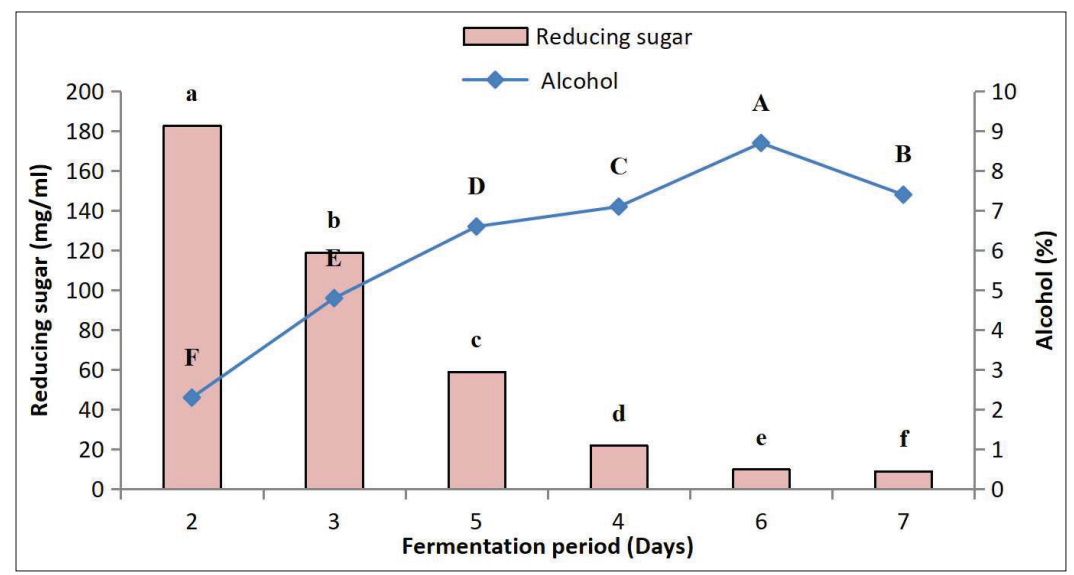

Figure 3: Changes in alcohol and reducing sugar content during fermentation of palmyrah molasses using baker's yeast. Values indicated by different letters (a-f), (A-F) are significantly different $(\mathrm{p}<0.05)$ 


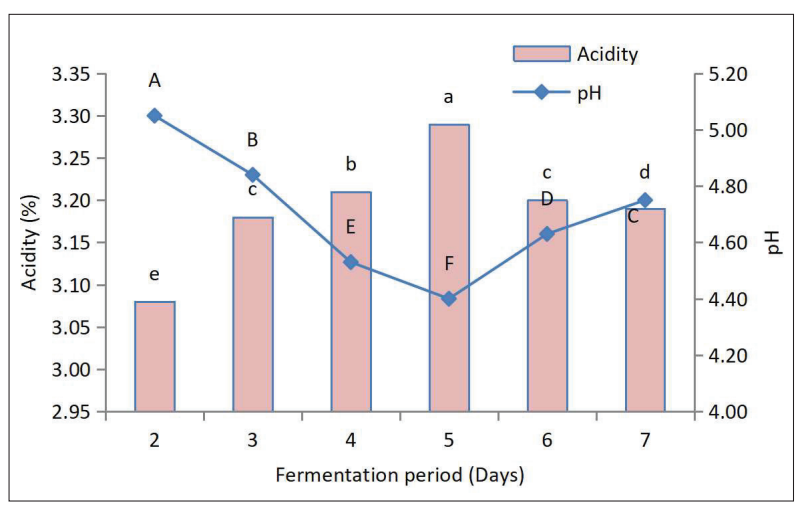

Figure 4: Changes in alcohol and reducing sugar content during fermentation of palmyrah molasses using baker's yeast. Values indicated by different letters (a-f), (A-F) are significantly different $(\mathrm{p}<0.05)$

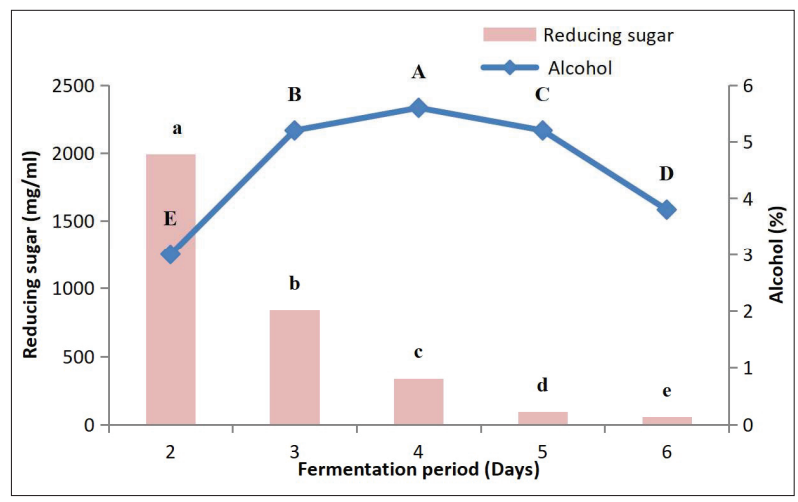

Figure 5: Changes in alcohol and reducing sugar content during fermentation of palmyrah fruit pulp (PFP) using baker's yeast. Values indicated by different letters (a-e), (A-E) are significantly different $(\mathrm{p}<0.05)$.

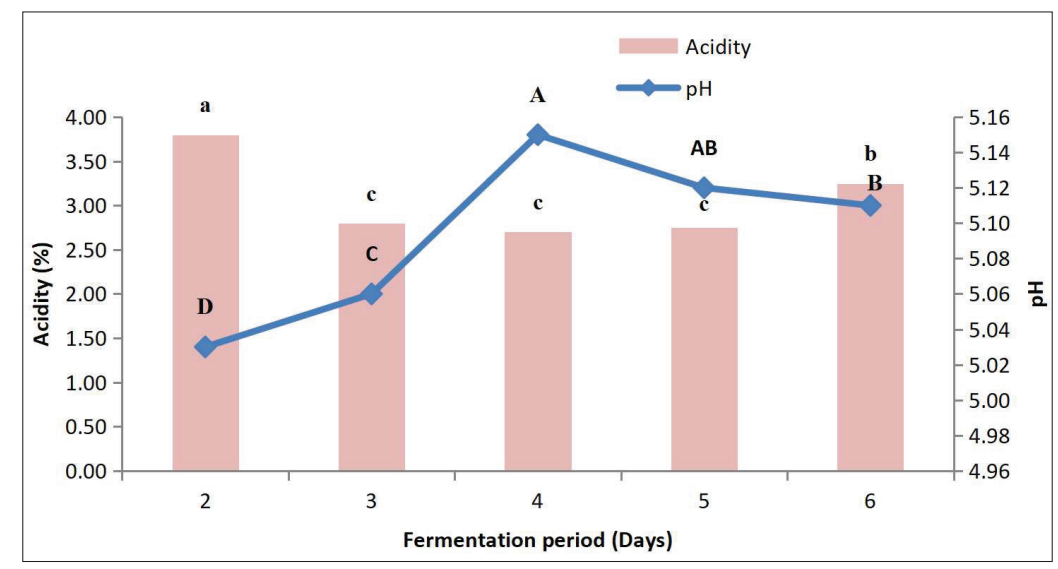

Figure 6: Changes in acidity and $\mathrm{pH}$ value during fermentation of palmyrah fruit pulp (PFP) using baker's yeast. Values indicated by a different letters (a-c), (A-D) are significantly different $(\mathrm{p}<0.05)$

\section{Production of alcohol from molasses}

Production of alcohol from molasses $\left(\right.$ brix $\left.^{\circ} 15\right)$ increased from the $2^{\text {nd }}$ to $6^{\text {th }}$ day of fermentation (Figure 3 ). The maximum production of alcohol was obtained on the $6^{\text {th }}$ day of fermentation. The amount of reducing sugar decreased from $2^{\text {nd }}$ to $7^{\text {th }}$ day of fermentation.

The total acid produced with molasses increased from the $2^{\text {nd }}$ to the $5^{\text {th }}$ day of fermentation. It then decreased from $6^{\text {th }}$ to the $7^{\text {th }}$ day of fermentation. The $\mathrm{pH}$ value decreased from the $2^{\text {nd }}$ to the $5^{\text {th }}$ day of fermentation and increased from $6^{\text {th }}$ to $7^{\text {th }}$ day of fermentation (Figure 4).

\section{Production of alcohol from PFP}

Production of alcohol increased from the $2^{\text {nd }}$ to $4^{\text {th }}$ day of fermentation and then it decreased. The highest alcohol production was $(5.5 \%)$ observed on the 4th day of fermentation. The amount of reducing sugar from PFP decreased during fermentation (Figure 5). The $\mathrm{pH}$ of the PFP added media increased from $2^{\text {nd }}$ to $4^{\text {th }}$ day of fermentation and then decreased from $5^{\text {th }}$ to $6^{\text {th }}$ day of fermentation. The acidity decreased from $2^{\text {nd }}$ to $3^{\text {rd }}$ day of fermentation and remained without any significant change on the $3^{\text {rd }}, 4^{\text {th }}$ and $5^{\text {th }}$ day of fermentation, and then increased on the $6^{\text {th }}$ day of fermentation (Figure 6). 
Table 6: Efficiency of alcohol fermentation from different palmyrah waste materials

\begin{tabular}{lcccc}
\hline & $\begin{array}{c}\text { Initial total sugar } \\
\text { content }(\mathrm{g})\end{array}$ & $\begin{array}{c}\text { Expected value } \\
(\mathrm{V} / \mathrm{V})\end{array}$ & $\begin{array}{c}\text { Observed } \\
\text { value } \mathrm{V} / \mathrm{V})\end{array}$ & $\begin{array}{c}\text { Efficiency } \\
(\%)\end{array}$ \\
\hline Molasses & 15.51 & 9.92 & 8.6 & 86.6 \\
PFP & 10.57 & 6.76 & 5.5 & 81.2 \\
Coir dust acid hydrolysed & 3.28 & 2.09 & 0.4 & 19.0 \\
\hline
\end{tabular}

\section{Efficiency of fermentation}

The efficiency of alcohol fermentation by yeast was significantly lower (19\%) in coir dust acid hydrolysate when compared with molasses $(86.6 \%)$ and expired PFP pulp $(81.2 \%)$ of palmyrah (Table 6$)$.

\section{Discussion}

There have been continuous studies to investigate the effects of diverse lignocellulosic substrates in the production of bioethanol (Azzam, 1987; Wright, 1988; Cadoche \& López, 1989; Reshamwala et al., 1995; Bjerre et al., 1996; Kathirgamanathan et al., 2017). Conversion of natural lignocellulosic material to ethanol includes two steps: hydrolysis of cellulose to fermentable reducing sugars and fermentation of the sugars to ethanol. In this research, coir dust was used for the secondary ethanol production. Further as a comparison, molasses obtained from sugar candy production and expired PFP were also used for the primary ethanol production.

The aim of the pre-treatment of coir dust was to break down the structure of lignin and interrupt the crystalline structure of cellulose as this will facilitate the acids or bases to easily hydrolyse the cellulosic materials (Duff \& Murray, 1996). Dilute acid hydrolysis could be used for pre-treatment of lignocellulosic materials, and this can achieve higher reaction rates and significantly improve cellulose hydrolysis (Mosier et al., 2005). In this study, $3 \% \mathrm{H}_{2} \mathrm{SO}_{4}$ acid was selected as the best pre-treatment agent at $121{ }^{\circ} \mathrm{C}$ for $45 \mathrm{~min}$. It produced a small but significant amount of ethanol. However, there was no alcohol produced from the $\mathrm{HNO}_{3}$ pre-treated hydrolysate. This may be due to the formation of toxic substances or inhibitors (Taherzadeh \& Karimi, 2007). Some pre-treatments carried out particularly at low $\mathrm{pH}$ would lead to the formation of different types of inhibitors such as carboxylic acids, furans and phenolic compounds (Esteghlalian et al., 1997). These chemicals may not affect the enzymatic hydrolyses, but they usually inhibit the microbial growth and fermentation, resulting less ethanol yield.

During the initial fermentation period of pulp and molasses, there was an increase in the alcohol content, and this may be due to fermentation where yeasts grow on sugar to release pyruvic acid via glycolysis. Then the acetaldehyde produced will be reduced by nicotinamide adenine dinucleotide (NAD) to form ethyl alcohol (Singh et al., 2003). Metabolic activities of yeasts that produce the ethanol and other metabolic by-products such as esters, ketones and higher alcohols are due to the efficient fermentation mechanism (Hansen, 1999; Piškur et al., 2006; Fernando \& Kapilan, 2019). During prolonged fermentation of the pulp, the amount of alcohol and acid produced showed a decrease, and this may be due to the formation of esters and higher alcohols.

The fermentation efficiency of coir dust was low compared with molasses and PFP. This may be due to the formation of inhibitors during the acid pre-treatment that inhibits or prevent the process of fermentation. In the presence of higher sugar concentration, furfural, a pentose degradation product and 5-hydroxymethylfurfural (HMF), a hexose degradation product will act as inhibitors. Lignin degradation products are formed during the fermentation of coir dust, and this leads to the reduction of ethanol yield from coir dust to a considerable amount. Therefore, it could be suggested that formation of inhibitors needs to be avoided or their effect minimized by a detoxification processe. Inhibition of fermentation is a multifactor effect that depends on different internal and external factors of palmyrah such as the type of substrate, type and amount of microorganisms present in the substrate, surface exposed to microbial interaction and the biochemical reaction between the substrates and the microorganisms (Parekh et al., 2000, Kapilan, 
2015, Kapilan et al., 2015, Sarathadevi et al., 2018). During the hydrolysis of coir dust, non-fermentable sugars were also produced, which lowered the efficiency of fermentation of coir dust acid hydrolysate, when compared with molasses and expired PFP. Bioethanol production from coir dust substrate could be improved by developing enzymatic pre-treatment technologies in addition to the acid hydrolysis and optimization of fermentation medium (Panday, 1992; Parekh et al., 2000; Kathirgamanathan et al., 2017). Because of the absence or minimal level of accumulation of inhibitory substances in molasses and PFP, the amount of ethanol yield was significantly higher in molasses and PFP of palmyrah than in coir dust during fermentation. When the feasibility and the economics are considered, there will not be any issue in using molasses and PFP of the palmyrah palm as the raw material for bioethanol production. However, the novelty of this study is the usage of coir dust as a raw material for bioethanol production. With planning, obtaining coir dust from the palm can be made easy and cost-effective. Among the different palmyrah waste materials for bioethanol production, molasses and PFP could be treated as primary substrates and coir dust could be a secondary substrate.

\section{CONCLUSION}

Among the palmyrah palm wastes tested as starting materials for bioethanol production, molasses and palmyrah fruit pulp were more efficient than coir dust. Among the acids $\mathrm{H}_{2} \mathrm{SO}_{4}, \mathrm{HNO}_{3}$ and $\mathrm{HCl}$ and bases $\mathrm{NaOH}$ and $\mathrm{Ca}(\mathrm{OH})_{2}$ used for the pre-treatment, $\mathrm{H}_{2} \mathrm{SO}_{4}$ is the best hydrolysing agent for coir dust. Although the efficiency of alcohol production from coir dust was comparatively low, it could also be considered as a substrate for bio-ethanol production considering the excessive amount under-utilized in regular practice. This preliminary study concludes that the pre-treatment of palmyrah coir dust with $3 \% \mathrm{H}_{2} \mathrm{SO}_{4}$ for $45 \mathrm{~min}$ and fermentation by yeast on PYN medium at pH 5.0 and at $30{ }^{\circ} \mathrm{C}$ for 4 days could be effectively used for bioethanol production from coir dust with further optimization.

\section{Conflict of interests}

The authors declare that they have no competing interests.

\section{Acknowledgements}

The authors express their sincere gratitude to the Ministry of Prison Reforms, Rehabilitation, Resettlement and Hindu Religious Affairs, Sri Lanka for the financial support.

\section{REFERENCES}

Azzam A.M. (1987). Saccharification of bagasse cellulose pretreated with $\mathrm{ZnCl}_{2}$ and $\mathrm{HCl}$. Biomass and Bioenergy 12: 71-77.

DOI: https://doi.org/10.1016/0144-4565(87)90009-6

Asiri Nisansala D., Piraveena G. \& Kapilan R. (2021). Palmyrah (Borassus flabellifer) Nature's Gift for Life. Aarani Publishers, Jaffna.

Barker H.A., Ruben S. \& Kamen M.D. (1940). The reduction of radioactive carbon dioxide by methane-producing bacteria. Proceedings of the National Academy of Sciences of USA 26: 426-430.

DOI: https://doi.org/10.1073/pnas.26.6.426

Balakumar S. \& Arasaratnam V. (2009). Comparison of industrial scale ethanol production from a palmyrah-based carbon source by commercial yeast and a mixed culture from palmyrah toddy. Journal of the Institute of Brewing 115(2): 105-110. DOI: https://doi.org/10.1002/j.2050-0416.2009.tb00353.x

Bjerre A.B., Olesen A.B. \& Fernqvist T. (1996). Pretreatment of wheat straw using combined wet oxidation and alkaline hydrolysis resulting in convertible cellulose and hemicellulose. Biotechnology and Bioengineering 49: 568-577.

DOI: https://doi.org/10.1002/(SICI)1097-0290(19960305) 49:5<568::AID-BIT10>3.0.CO;2-6

Cadoche L. \& López G.D. (1989). Assessment of size reduction as a preliminary step in the production of ethanol from lignocellulosic wastes. Biological Wastes 30: 153-157. DOI: https://doi.org/10.1016/0269-7483(89)90069-4

Chan L., Kit N.C.V, Khim W.C.X., Kent L.H. \&Yip C.H. (2011). Determination of Acid Content in Vinegar - Volumetric Titration. University Malaysia Sabah, Malaysia.

Cortes T.R., Cuervo-Parra J.A., Robles-Olvera V.J., Cortes E.R. \& López Pérez P.A. (2018). Experimental and kinetic production of ethanol using mucilage juice residues from cocoa processing. International Journal of Chemical Reactor Engineering 16 (11).

Daroch M., Geng S. \& Wang G. (2013). Recent advances in liquid biofuel production from algal feed stocks. Applied Energy 102: 1371-1381.

DOI: https://doi.org/10.1016/j.apenergy.2012.07.031

Duff S.J.B. \& Murray W.D. (1996). Bioconversion of forest products industry waste cellulosics to fuel ethanol: a review. Bioresource Technology 55: 1-33. DOI: https://doi.org/10.1016/0960-8524(95)00122-0

Esteghlalian A., Hashimoto A.G., Fenske J.J. \& Penner M.H. (1997). Modeling and optimization of the dilute-sulfuricacid pre-treatment of corn stover, poplar and switch grass. Bioresource Technology 59(2): 129-136. DOI: https://doi.org/10.1016/S0960-8524(97)81606-9

Fernando M.N. \& Kapilan R. (2019). Biodiesel production from Sargassum sp. a SriLankan marine flora and optimization of conditions for yield enhancement, Proceedings of the Vavuniya Campus International Research Symposium, pp. 99-103. 
Hansen J. (1999). Inactivation of MXR1 abolishes formation of dimethyl sulfide from dimethyl sulfoxide in Saccharomyces cerevisiae. Applied and Environmental Microbiology 65: 3915-3919. DOI: https://doi.org/10.1128/AEM.65.9.3915-3919.1999

Hill J., Nelson E., Tilman D., Polasky S. \& Tiffany D. (2006). Environmental, economic, and energetic costs and benefits of biodiesel and ethanol biofuels. Proceedings of the National Academy of Sciences 103(30): 11206-11210. DOI: https://doi.org/10.1073/pnas.0604600103

Kapilan R. (2015). Optimization of the usage of commercial lime for the inhibition of fermentation of sweet sugary saps of Borassus flabellifer and Caryota urens. International Journal for Advanced Research in Biological Sciences 2(12): 60-66.

Kapilan R., Robika K., Mahilrajan S. \& Srivijeindran S. (2015). Efficient fermentation inhibitor of sweet phloem sap of Palmyrah (Borassus flebellifer L.) in Sri Lanka. International Journal of Advanced Research in Biological Sciences 2(10): 89-95.

DOI: https://doi.org/10.12983/ijsras-2015-p0166-0174

Kapilan R. (2015). Solid state fermentation for microbial products: A review. Archives of Applied Science Research 7(8): 21-25.

Kathirgamanathan M., Abhayasekera C.L., Kulasooriya S.A., Wanigasekera A. \& Ratnayake R.R. (2017). Evaluation of 18 isolates of basidiomycetes for Lignocellulose degrading enzymes. Ceylon Journal of Science 46(4): 77-84.

DOI: https://doi.org/10.4038/cjs.v46i4.7470

Miller G.L. (1959). Use of dinitrosalicylic acid reagent for determination of reducing sugar. Analytical Chemistry 31(3): 426-428.

DOI: https://doi.org/10.1021/ac60147a030

Mohanadas K. (2002). The palmyrah palm and the composition of palmyrah fruit pulp. Sivapathasuntharam Mageswaran Memorial Lecture. University of Jaffna.

Mosier N.S., Wyman Dale B., Elander R., Lee Y.Y., Holtzapple M. \& Ladisch M.R. (2005). Features of promising technologies for pre-treatment of lignocellulosic biomass. Bioresource Technology 96: 673-686.

DOI: https://doi.org/10.1016/j.biortech.2004.06.025

Nigam P.S. \& Singh A. (2011). Production of liquid biofuels from renewable resources. Progress in Energy and Combustion Science 37(1): 52-68.

DOI: https://doi.org/10.1016/j.pecs.2010.01.003

Parekh S., Vinci V.A. \& Strobel R.J. (2000). Improvement of microbial strains and fermentation processes. Applied Microbiology and Biotechnology 54(3): 287-301. DOI: https://doi.org/10.1007/s002530000403

Pandey A. (1992). Recent process developments in solid-state fermentation. Process Biochemistry 27: 12-17.
DOI: https://doi.org/10.1016/0032-9592(92)80017-W

Piškur J., Rozpędowska E., Polakova S., Merico A. \& Compagno C. (2006). How did Saccharomyces evolve to become a good brewer? Trends in Genetics 22: 183-186. DOI: https://doi.org/10.1016/j.tig.2006.02.002

Potrich E. \& Amaral L.S. (2018). Activation energy, half-life and yield of the hydrolysis reaction of sucrose catalyzed by the enzyme invertase produced by yeast Saccharomyces cerevisiae. International Journal of Current Microbiology and Applied Sciences 7(2): 806-816.

DOI: https://doi.org/10.20546/ijcmas.2018.702.102

Qureshi N. \& Blaschek H.P. (2005). Butanol production from agricultural biomass. In: Food Biotechnology (eds. K. Shetty, A. Pometto \& G. Paliyath), pp. 525-551. Taylor and Francis Group, Boca Raton, Florida, USA.

DOI: https://doi.org/10.1201/9781420027976.ch1.20

Refai-El A.H., El-Abyad M.S., El-Diwany A.I., Sallam L.A. \& Allam F. (1992). Some physiological parameters for ethanol production from beet molasses by Saccharomyces cerevisiae Y-7. Bioresource Technology 42(3): 183-189. DOI: https://doi.org/10.1016/0960-8524(92)90021-O

Reshamwala S., Shawky B.T. \& Dale B.E. (1995). Ethanol production from enzymatic hydrolysates of AFEXtreated coastal Bermuda grass and switch grass. Applied Biochemistry and Biotechnology 51/52: 43-55.

DOI: https://doi.org/10.1007/BF02933410

Sarathadevi R., Kapilan R. \& Vasantharuba S. (2018). Papaw fruit juice as source for single cell protein production using natural palmyrah toddy yeast. Ceylon Journal of Science 47(4): 379-386.

DOI: https://doi.org/10.4038/cjs.v47i4.7556

Sarkar N., Ghosh S.K., Bannerjee S. \& Aikat K. (2012). Bioethanol production from agricultural wastes: An overview. Renewable Energy 37(1): 19-27.

DOI: https://doi.org/10.1016/j.renene.2011.06.045

Singh D.P. \& Trivedi R.K. (2003). Acid and alkaline pretreatment of lignocellulosic biomass to produce ethanol as biofuel. International Journal of Chem Tech Research 5: 727-734.

Taherzadeh M.J. \& Karimi K. (2007). Acid-based hydrolysis processes for ethanol from lignocellulosic materials: A review. BioResources 2: 472-499.

Theivendirarajah K. (2008). Palmyrah Palm, $1^{\text {st }}$ edition. Graph Arts Print, Jaffna.

Vasudevan P.T. \& Briggs M. (2008). Biodiesel production: current state of the art and challenges. Journal of Industrial Microbiology and Biotechnology 35: 421-430. DOI: https://doi.org/10.1007/s10295-008-0312-2

Wright J.D. (1988). Ethanol from biomass by enzymatic hydrolysis. Chemical Engineering Progress 84(8): 62-74. 